\title{
KAJIAN BUDAYA DAN IKLIM DALAM ORGANISASI PENDIDIKAN
}

\author{
Haromain \\ Program Studi Administrasi Pendidikan, FIPP UNDIKMA \\ Email: haromain@ikipmataram.ac.id
}

\begin{abstract}
Abstrak: Setiap organisasi memiliki karakteristik tersendiri yang membedakannya dengan organisasi lainnya. Demikian halnya dengan organisasi pendidikan. Budaya dan iklim organisasi pendidikan khususnya sekolah menjadi bagian yang cukup memiliki pengaruh terhadap tujuan pencapaian pendidikan. Keefektifan organisasi pendidikan sangat dipengaruhi oleh budaya yang diterapkan dalam organisasi tersebut. Perwujudan dari budaya tersebut adalah iklim organisasi yang dapat dirasakan oleh setiap anggota organisasi.
\end{abstract}

Kata Kunci: Budaya, Iklim, Organisasi, Pendidikan

\section{PENDAHULUAN}

Setiap individu memiliki kepribadian, begitu pula dengan organisasi. Sebagaimana individu yang memiliki kepribadian yang menjadi karakteristiknya yang berbeda antara individu satu dengan lainnya, demikian halnya dengan karakteristik organisasi yang menjadi pembeda dengan organisasi lainnya. Karakteristik organisasi ini menjadi ciri khas yang menjadi penanda sebuah organisasi. Dalam hal ini, sebagaimana individu, organisasi dapat digolongkan sesuai dengan sifat-sifat yang dimilikinya. Sifat-sifat inilah yang selanjutnya dapat digunakan untuk memperkirakan sikap dan prilaku individu yang ada dalam organisasi.

Terdapat suatu variabel dalam organisasi yang memiliki peran yang sangat menentukan dalam pencapaian tujuan organisasi, yang walaupun sukar untuk ditentukan atau diuraikan secara seksama tatapi variabel itu ada, dan variabel tersebut biasanya diuraikan oleh prilaku orang-orang yang ada dalam organisasi dalam bentukbentuk yang umum sekali. Variabel tersebut seringkali kita sebut dengan istilah budaya dan iklim organisasi. Sebagaimana budayabudaya suku memiliki totem dan pantangan yang mengatur bagaimana masing-masing anggota suku bertindak terhadap anggota suku dan orang lain diluar sukunya, maka suatu organisasi juga memiliki budaya yang mengatur bagaimana anggota-anggotanya bersikap.

Iklim organisasi juga menjadi sesuatu yang menarik untuk dikaji, dikarenakan kedua variabel dalam organisasi ini dapat dikatakan menjadi penentu bagi keefektifan organisasi dalam mencapai tujuannya. Jika diibaratkan sebuah senter, maka iklim organisasi adalah lampunya sedangkan budaya organisasi adalah baterainya. Sangat jelas sekali senter itu tidak bisa menyala jika baterainya tidak ada. Demikian pula dengan organisasi, Iklim yang ada dalam organisasi sangat ditentukan oleh bagaimana budaya yang berkembang dalam organisasi tersebut.

Berdasarkan uraian tersebut diatas, artikel ini membahas tentang budaya organisasi yang mencakup komponen, fungsi, karakteristik, klasifikasi, bagaimana membentuk dan mempertahankan budaya organisasi. Hal lain yang juga dibahas adalah tentang iklim organisasi yang berisi komponen serta hasil-hasil penelitian tentang iklim organisasi yang pernah dilakukan.

\section{KAJIAN PUSTAKA}

\section{Budaya Organisasi}

Terdapat kesepakatan luas bahwa budaya organisasi merujuk pada sistem pengertian bersama yang dipegang oleh anggota-anggota suatu organisasi yang membedakan organisasi tersebut dengan organisasi lainnya (Robbins, 2005:485). Sistem pengertian bersama ini dalam pengamatan yang lebih seksama merupakan serangkaian karakter penting yang menjadi nilai bagi suatu organisasi.

Budaya organisasi mengacu pada normaprilaku, asumsi, dan keyakinan dari suatu organisasi, sementara dalam iklim organisasi mengacu pada persepsi orangorang dalam organisasi yang merefleksikan norma-norma, asumsi-asumsi dan keyakinan (Owens, 1991). Sedangkan Sonhadji(2003) 
mengatakan bahwa budaya organisasi adalah proses sosialisasi anggota organisasi untuk mengembangkan persepsi, nilai dan keyakinan terhadap organisasi untuk mengembangkan persepsi, nilai, dan keyakinan terhadap organisasi. Sementara Soetopo (2010) mengatakan bahwa budaya organisasi berkenaan dengan keyakinan, asumsi, nilai, norma-norma prilaku, ideology, sikap, kebiasaan dan harapan-harapan yang dimiliki oleh organisasi (dalam hal ini termasuk organisasi universitas swasta).

Gibson, Ivanichevich\&Donelly dalam Soetopo (2010) berpendapat bahwa budaya organisasi adalah "kepribadian organisasi yang mempengaruhi cara bertindak individu dalam organisasi".

Dari semua definisi tentang budaya organisasi diatas, secara umum dapat ditetapkan bahwa budaya organisasi berkaitan dengan makna bersama, nilai, sikap dan keyakinan. Dapat dikatakan bahwa jantung dari suatu organisasi adalah sikap, keyakinan, kebiasaan dan harapan dari seluruh individu anggota organisasi mulai dari manajemen puncak hingga manajemen yang paling rendah, sehingga tidak ada aktifitas manajemen yang dapat melepaskan diri dari budaya.

\section{Komponen-Komponen Budaya Organisasi}

Robbins dalam Soetopo (2010) mengemukakan tujuh karakteristik budaya organisasi yaitu:

Pertama, otonomi individu yaitu kadar kebebasan, tanggung jawab dan kesempatan individu untuk berinisiatif dalam organisasi. Kedua, struktur yaitukadar peraturan dan ketetapan yang digunakan untuk mengontrol prilaku pegawai. Ketiga, dukungan yaitu kadar bantuan dan keramahan manajer kepada pegawai. Keempat, identitas yaitu kadarkenalnya anggota terhadap organisasinya secara keseluruhan, terutama informasi kelompok kerja dan keahlian profesionalnya. Kelima, hadiah performansi yaitu kadar alokasi hadiah yang didasarkan pada criteria performansi pegawai. Keenam, toleransi konflik yaitu kadar konflik dalam hubungan antar sejawat dan kemauan untuk jujur dan terbuka terhadap perbedaan. Ketujuh, toleransi resiko yaitu kadar dorongan terhadap pegawai untuk agresif, inovatif dan berani menanggung resiko.

\section{Fungsi Budaya Organisasi}

Soetopo (2010) mengemukan bahwa fungsi budaya organisasi bergayut dengan fungsi eksternal dan fungsi internal. Fungsi eksternal budaya organisasi adalah melakukan adaptasi terhadap lingkungan diluar organisasi, sementara fungsi internal berkaitan dengan integrasi berbagai sumber daya yang ada didalamnya termasuk sumber daya manusia.

Robbins (2005) mengemukakan tentang fungsi budaya dalam organisasi menjadi lima fungsi yaitu:

Pertama, budaya memiliki suatu peran batas-batas tertentu yaitu budaya menciptakan perbedaan antara satu organisasi dengan organisasi lainnya. Kedua, budaya menyampaikan rasa identitas kepada anggotaanggota organisasi. Ketiga, budaya mempermudah penerusan komitmen hingga mencapai batasan yang lebih luas, melebihi batasan ketertarikan individu. Keempat, budaya mendorong stabilitas sistem sosial. Dan kelima, budaya sebagai pembentuk rasa dan mekanisme pengendalian yang memberikan panduan dan bentuk prilaku serta sikap karyawan.

Robbins menjelaskan bahwa budaya yang kuat selalu ditandai oleh nilai-nilai inti organisasi yang dipegang kukuh dan disepkati secara luas. Semakin banyak anggota organisasi yang menerima nilai-nilai inti dan semakin besar komitmen mereka terhadap nilai-nilai tersebut, maka budaya tersebut akan semakin kuat. Sejalan dengan definisi ini, suatu budaya yang kuat jelas sekali memiliki pengaruh yang besar dalam sikap anggota organisasi dibandingkan dengan budaya yang lemah.

Hasil spesifik dari suatu budaya yang kuat adalah keluar masuknya pekerja yang rendah. Suatu budaya yang kuat akan memperlihatkan kesepakatan yang tinggi mengenai tujuan organisasi diantara anggotaanggotanya. Kebulatan suara terhadap tujuan 
akan membentuk keterikatan, kesetiaan, dan komitmen organisasi. Kondisi ini selanjutnya akan mengurangi kecendrungan karyawan untuk keluar dari organisasi.

\section{HASIL DAN PEMBAHASAN}

Karakteristik Budaya Organisasi

O'Reilly dan Jehn dalam Soetopo (2010) mengemukakan tujuh karakteristik utama yang menjadi inti dari suatu organisasi, yaitu:

Pertama,innovation and risk taking, yaitu derajat sejauh mana pekerja didorong untuk inovatif dan berani mengambil resiko. Kedua, attention to detail,yaitu derajat seajuh mana para pekerja diharapkan menunjukkan presisi, analisis, dan perhatian pada detaildetail. Ketiga, outcome orientation,yaitu sejauh mana pimpinan berfokus pada hasil, bukan pada teknis dari proses yang dipakai untuk menjadi hasil. Keempat, people orientation, yaitu sejauh mana keputusan manajemen memperhitungkan efek hasil-hasil pada orang dalam fungsi budaya organisasi menjadi inti dari suatu budaya organisasi. Kelima, team orientation,yaitu sejauh mana kegiatan kerja diorganisasikan atas dasar tim kerja daripada individu. Keenam, aggressiveness, yaitu sejauhmana orangorang dalam organisasi bersifat agresif dan kompeteitif. Dan ketujuh, stability, yaitu sejauh mana aktifitas organisasi menekankan pemeliharaan status quo sebagai kontras dari pertumbuhan.

Menilai suatu organisasi dengan ketujuh karakter ini akan menghasilkan gambaran mengenai budaya organisasi tersebut. Gambaran tersebut kemudian menjadi dasar untuk perasaan saling memahami yang dimiliki anggota organisasi mengenai organisasi mereka, bagaimana segala sesuatu dikerjakan berdasarkan pengertian bersama tersebut, dan cara-cara anggota organisasi seharusnya bersikap (Robbins, 2005;486).

\section{Klasifikasi Budaya Organisasi}

Dalam mempelajari budaya organisasi, terdapat empat pendekatan menurut Robert dan Hunt dalam Soetopo (2010). Keempat pendekatan itu antara lain: (1) beberapa sarjana memandangnya sebagai asumsi bersama, keyakinan dan nilai-nilai dalam organisasi dan kelompok kerja, (2) kelompok kedua tertarik dengan mitos, cerita, dan bahasa sebagai manifestasi budaya, (3) memandang tata cara dan seremonial sebagai manifestasi budaya, dan (4) mempelajari interaksi antar anggota dan symbol-simbol.

\section{ORIENTASI KONTROL FORMAL}

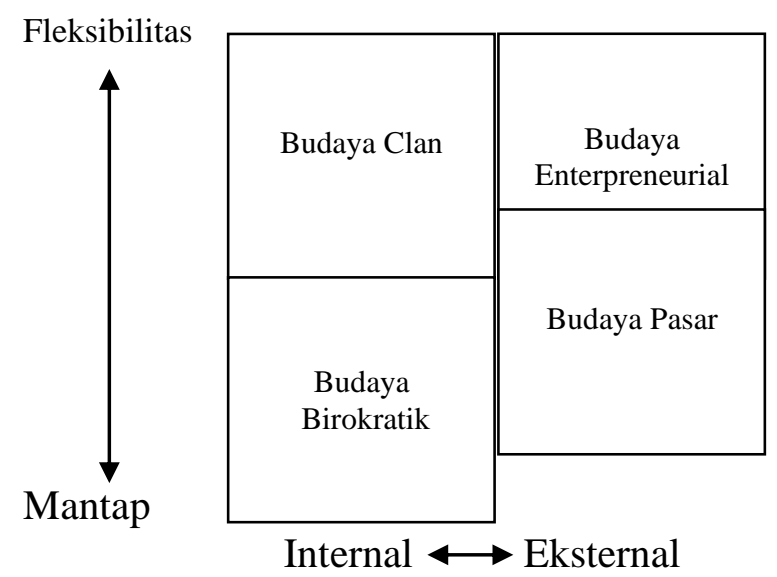

Sumbu vertical mencerminkan orientasi pengawasan yang relative normal, jarak dari mantap ke fleksibel. Sumbu horizontal mencerminkan fokus relative terhadap perhatian, jarak dari fungsi internal ke fungsi eksternal. Sudut-sudut dari empat persegi mewakili empat tipe murni dari budaya organisasi yaitu birokratik, clan, entrepreneurial dan pasar.

Budaya birokratik mencerminkan suatu organisasi dengan karyawan yang mempunyai formalisasi nilai peraturan standar prosedur operasi dan koordinasi hierarkis.Budaya clan mempunyai atribusi tradisi, kesetiaan, komitmen pribadi, sosialisasi ekstensif, tim kerja, manajemen diri dan pengaruh sosial. Sementara budaya entrepreneurial, menunjukkan tingkat pengambilan resiko yang tinggi, dinamis dan kreatifitas. Sedangkan budaya pasar menekankan padanilai yang akan dicapai terukur, dan karyawan dituntut untuk mencapai sasaran, terutama yang berbasis finansial dan pasar. 


\section{Menciptakan dan Mempertahankan Budaya}

Suatu budaya dalam organisasi tidak muncul begitu saja. Bila sudah terbentuk mantap, budaya tidak akan menghilang begitu saja. Kebiasaan, tradisi, dan cara-cara umum dalam mengerjakan sesuatu yang sudah ada dalam suatu organisasi berkaitan erat dengan apa yang telah dilakukan sebelumnya dan dnegan tingkat keberhasilan organisasi tersebut dengan upaya-upayanya. Dengan demikian sumber utama budaya organisasi tersebut adalah para pendirinya (Robbins, 2005; 492)

Para pendiri organisasi secara tradisional memiliki pengaruh yang dalam membentuk budaya awal. Mereka memiliki visi bagaimana wujud organisasi tersebut. Mereka tidak dibatasi oleh kebiasaankebiasaan dalam menegrjakan sesuatu atau ideologi-ideologi sebelumnya. Pemberian karakter terhadap organisasi-organisasi baru dengan ruang lingkup yang masih kecil, mempermudah para pendiri dalam menerapkan visinya pada keseluruhan anggota organisasi. Dikarenakan para pendiri tersebut memiliki ide yang masih asli, mereka juga biasanya memiliki bias tentang cara bagaimana ide-ide tersebut bisa terpenuhi. Budaya organisasi dihasilkan dari interaksi antara bias dan asumsi para pendiri dengan apa yang dipelajari selanjutnya oleh anggota awal organisasi dari pengalaman mereka sendiri.

Bila suatu budaya sudah berlaku dalam suatu organiasi, praktik-praktik dalam organisasi berfungsi untuk menjaga budaya tersebut dengan cara mengekspos karyawan agar memiliki pengalaman yang serupa (Robbins, 2005; 493).

\section{IKLIM ORGANISASI}

Owens (1991) menyatakan bahwa "organizational climate is the study of perceptions that individual have of various aspect of the environment in the organization". Dengan demikian pengkajian iklim organisasi dapat dilakukan dengan menggali data dari persepsi individu yang ada dalam organisasi. Taguiri dan Litwin dalam
Soetopo (2010) mengartikan iklim organisasi adalah suatu kualitas lingkungan internal organisasi yang dialami oleh anggotanya, mempengaruhi prilakunya dan dapat dideskripsikan dengan nilai-nilai karakteristik organisasi.

\section{Klasifikasi Iklim Organisasi}

Berdasarkan hasil penelitian yang dilakukan oleh Halpin (1971) yang menggunakan Organizational Climate Description Quesionare $(O C D C)$, terdapat enam klasifikasi iklim organiasi yaitu:

Pertama, open

climateyang menggambarkan tentang situasi dimana anggota organisasi merasa senang untuk bekerja, saling kerjasama serta adanya keterbukaan. Kedua, outonomous climate yaitu situasi dimana adanya kebebasan, adanya peluang kreatif, sehingga para anggota memiliki peluang untuk memuaskan kebutuhan-kebutuhan mereka. Ketiga, the controlled climateyang ditandai adanya penekanan atas prestasi dalam mewujudkan kepuasan kebutuhan social, setiap orang bekerja keras serta kurangnya hubungan antar sesama anggota. Keempat, the familiar climateyaitu adanya rasa kesejawatan tinggi antara pimpinan dan anggota

Selanjutnya yang kelima adalah the paternal climateyang bercirikan adanya pengontrolan pimpinan terhadap anggota. Dan keenam, the closed climateyang ditandai suatu situasi rendahnya kepuasan dan prestasi tugas serta kebutuhan sosial para anggota, pimpinan sangat tertutup terhadap para anggotanya.

Dari keenam klasifikasi iklim organisasi berdasarkan OCDC tersebut, Halpin kemudian mengelompokkan iklim organiasasi secara garis besar menjadi dua yaitu open climate dan closed climate. Pengklasifikasian ini bukanlah pemilahan secara diskrit tetapi merupakan kontinum dari terbuka sampai kepada tertutup. Pertanyaanya adalah apakah kecendrungan terbuka atau tertutupnya iklim organisasi akan diikuti oleh makin tinggi atau rendahnya keefektifan organisasi? Hal inilah yang perlu dikaji secara empirikdilapangan. 
Hasil penelitian Miner ini sebagaimana dikutip dalam Soetopo (2010) menunjukkan bahwa manajer yang bekerja dalam iklim organisasi terbuka menunjukkan pekerjaan yang lebih baik daripada manajer yang bekerja dalam iklim organisasi yang tertutup. Hoy and Miskel (2005) mengemukakan bahwa organisasi yang memiliki situasi kerja dengan iklim terbuka menunjukkan tingkat kepercayaan dan keefektifan lebih tinggi daripada menggunakan iklim tertutup.

Berdasarkan paparan diatas, dapat ditarik kesimpulan bahwa pemimpin yang menggunakan orientasi hubungan kemanusiaan akan lebih menopang iklim organisasi yang terbuka (member kepercayaan, menghargai) daripada pemimpin yang menggunakan otorientasi tugas.

\section{Penelitian Iklim Organisasi}

Berdasarkan hasil penelitian Halpin dan Croft tentang iklim organisasi yang dilakukan pada 71 sekolah dasar yang ada di 6 wilayah Amerika Serikat sebagaimana dikutip dalam Soetopo (2010), dapat digambarkan mengenai enam iklim organisasi, yaitu :

\section{The Open Climate}

The Open Climate menggambarkan suatu situasi dimana para anggota senang sekali esprityang tinggi. Guru-guru bekerja bersama dengan baik tanpa cekcok dan keluhan (disengagementrendah). Mereka tidak dibebani oleh menggunungnya kerja sibuk atau oleh laporan-laporan rutin; kebijakan kepala sekolah mempermudah pemenuhan guru akan tugas-tugasnya (hindrance rendah). Pada intinya, semua anggota kelompok mempunyai hubungan yang menyengangkan satu sama lain, tetapi mereka tidak terlalu memerlukan tingkat intimacyyang tinggi. Guru mencapai kepuasan kerja yang cukup tinggi, dan cukup terdorong untuk mengatasi kesulitan dan frustasinya. Mereka memperoleh insentif untuk menegrjakan sesuatu dan membuat organisasi "berjalan". Guru merasa bangga dengan sekolah itu.

Prilaku kepala sekolah merupakan integrasi antara kepribadiannya dan peranan yang ia mainkan sebagai kepala sekolah. Dalam hal ini prilakunya dapat dipandang sebagai asli. Dia tidak hanya memberikan contoh dengan bekerja keras (trust tinggi), tetapi bergantung situasi ia dapat juga mengkritik tindakan guru-guru atau keluar dari kebiasaan untuk membantu guru-guru (considerationtinggi). Ia mempunyai fleksibilitas untuk melakukan control dan mengarahkan aktivitas orang lain atau menunjukkan pemuasan kebutuhan social guru-guru secara individual. Ia tidak menyendiri, ia tidak membuat peraturan dan prosedur yang membuat tidak fleksibel dan tidak mempribadi. Ia tidak menekankan pada produksi, ia tidak memonitor aktivitas guru secara ketat, karena guru-guru bekerja dengan mudah dan bebas. Ia tidak melakukan semuanya karena ia memiliki kemampuan untuk melakukan tindakan kepemimpinan yang muncul dari guru (production empahsisrendah).

\section{The Outonomous Climate}

Wujud kerja dari iklim organisasi ini adalah hamper bebas sempurna, bahwa kepala sekolah memberikan kepada guruguru agar memberikan interaksi untuk strukturnya sendiri sehingga mereka dapat menemukan cara dalam kelompok untuk memuaskan kebutuhan-kebutuhan social mereka. skor-skornya lebih kepada pemuas kebutuhan social daripada ke pencapaian tugas (relative skor tinggi pada esprit dan intimacy).

Jika guru-guru berada pada situasi orientasi tugas, mereka mencapai tujuan dengan mudah dan cepat (disengagement rendah). Ada tekanan minoritas terhadap kelompok, tetapi stratifikasi yang ada pada angggota kelompok tidak menghalangi kelompok sebagai keseluruhan dari bekerja sama dengan baik. Guru-guru bekerja bersama dengan baik dan melaksanakan tugas-tugas organisasi.

Guru-guru tidak dibebani oleh tugastugas administratif, dan mereka tidak mengeluh untuk membuat laporan-laporan. Kepala sekolah menyusun prosedur dan tata aturan untuk mempermudah pelaksanaan 
tugas guru. Guru-guru tidak lari ke kepala sekolah setiap memerlukan peralatan mengajar, control yang memadai ditetapkan untuk menggambarkan tugas kepala sekolah dan guru-guru (hindrance rendah) semangat kerja tinggi karena adanya pemuasan kebutuhan social yang diterima oleh guruguru.

Kepala sekolah memberikan thrust untuk organisasi dengan memberikan contoh dan dengan kerja keras. Ia mempunyai fleksibilitas pribadi baik untuk control maupun untuk kesejahteraan guru-guru. Iklim ini bercirikan skor relatif tinggi pada esprit dan intimacy, disengagement rendah, hindrance rendah, aloofenesstinggi, production emphasis rendah dan consideration menengah.

\section{The Controlled Climate}

Iklim ini ditandai dengan tekanan pada prestasi dalam mewujudkan kepuasan kebutuhan social. Setiap orang bekerja keras, dan sedikit waktu untuk berhubungan dengan sesama atau untuk menyimpang dari control dan arah yang telah ditetapkan. Iklim ini terlalu memberi bobot pada prestasi tugas dan keluar dari kepuasan kebutuhan sosial. Namun demikian selama semangat tinggi (esprit), iklim ini dapat diklasifikasikan lebih opened daripada closed.

Iklim ini bercirikan disengagement rendah, hindrance tinggi, intimacy rendah, production emphasis tinggi, consideration rendah dan thrustmenengah.

\section{The Familiar Climate}

Keistimewaan iklim ini adalah kesejawatan yang tinggi, baik kepala sekolah maupun guru. Pemuasan kebutuhan social sangat tinggi, sementara sebaliknya kecil sekali control atau arahan kegiatan kelompok untuk mencapai tujuan.

Iklim ini bercirikan disengagement yang tinggi, hindrancerendah, intimacy tinggi, conciderationtinggi, aloofness rendah dan production emphasis rendah.

\section{The Paternal Climate}

Iklim ini bercirikan usaha yang tidak efektif dari kepala sekolah untuk mengontrol guru-guru, termasuk untuk memuaskan kebutuhan sosialnya.

\section{The Closed Climate}

Iklim ini ditandai oleh suatu situasi dimana anggota kelompok mencapai sedikit kepuasan dalam prestasi tugas atau kebutuhan social. Pendeknya, kepala sekolah tidak efektif dalam mengarahkan aktifitas para guru, pada waktu yang sama ia cenderung mencari kesejahteraan pribadi mereka.

Guru-guru tidak diikut sertakan dan tidak bekerja sama dengan baik, akibatnya prestasi kelompok menjadi minimal. Untuk mencapai prestasi, usaha guru adalah meelngkapi berbagai laporan dan mengerjakan tugas-tugas rumah. Kepala sekolah tidak mendorong pelaksanaan tugastugas guru. Kepala sekolah sangat aloof (mengasingkan diri) dan impersonal dalam mengontrol dan mengarahkan aktifitas guruguru. Ia menekankan produksi dan sering mengatakan "kita harus bekerja keras", tetapi kata-katanya keras karena ia sendiri mempunyai thrust yang rendah dan ia tidak memotivasi guru-guru dengan menunjukkan contoh yang baik. Dalam hal ini, ia tidak asli dalam tindakannya, tidak peduli dengan kebutuhan social guru-guru dan seperti tidak membuat pertimbangan.

Kata-kata "marilah bekerja keras" menjadi "kamu bekerja keras". Ia berharap orang lain membuat inisiatif, lagipula ia tidak member kebebasan kepada gur-guru. Ia sendiri tidak memberikan kepemimpinan yang memadai kepada kelompok. Dengan demikian guru-guru memandangnya tidak asli; mereka memandangnya sebagai seorang yang penuh kepalsuan.

\section{KESIMPULAN}

Organisasi sebagai wadah tempat berkumpulnya individu untuk mencapai tujuan-tujuannya sangat bergantung pada bagaimana individu-individu yang ada didalamnya memiliki asumsi, prilaku dan keyakinan terhadap organisasi. Budaya dan iklim organisasi menjadi variabel yang sangat 
menentukan dalam pencapaian tujuan Soetopo, Hendyat (2010). Perilaku organisasi yang efektif dan efisien. Organisasi; Teori dan Praktek di

Budaya organisasi haruslah dibentuk dengan memperhatikan aspek-aspek yang menjadi nilai-nilai positif bagi keberlangsungan pencapaian tujuan organisasi. Budaya yang sudah terbentuk ini kemudian harus mampu dipertahankan oleh organisasi tentunya melalui orang-orang yang ada dalam organisasi. Proses-proses yang berlangsung dalam organisasi sangat mempengaruhi keberadaan budaya organisasi. Semakin banyak orang-orang dalam organisasi yang memegang teguh budaya yang sudah dibentuk, maka budaya itu akanmenajdi semakin kuat. Demikian pula sebaliknya.

Hal lain yang penting dalam keberlangsungan sebuah organisasi adalah iklim organisasi. Iklim organisasi merupakan suatu kondisi atau cerminan dari budaya yang terbentuk. Ketika iklim organisasi tidak kondusif maka dapat dipastikan kepuasan kerja ataupun tujuan lain yang ingin dicapai oleh organisasi akan sulit diwujudkan. Maka seorang pemimpin dalam sebuah organisasi harus mampu menjaga atau mengkondisikan iklim organisasi agar selalu kondusif demi terwujudnya tujuan yang sudah ditentukan organisasi.

\section{DAFTAR PUSTAKA}

Hoy, K. Wayne \&Miskel, G. Cecil (2005). Educational Administration; Theory, Research, and Practice.The McGraw-Hill Companies, Inc. New York

Owens, G. Roberts (1995). Organizational Behavior in Education. Allyn and Bacon A Simon \& Schuster Company. Needham Heights.

Pace, R.W \&Faules, F.D (2002). Komunikasi Organisasi; Strategi Meningkatkan Kinerja Perusahaan. Bandung. Remaja Rosdakarya

Robbins, P. Stephen (2005). Organizational Behavior; Elevent Edition. Pearson Education.Inc., Upper Saddle, River. New Jersey 